\title{
The Effect of Probiotics on the Production of Short-Chain Fatty Acids by Human Intestinal Microbiome
}

\author{
Paulina Markowiak-Kopeć * and Katarzyna Śliżewska * \\ Institute of Fermentation Technology and Microbiology, Department of Biotechnology and Food Sciences, \\ Lodz University of Technology, 90-924 Łódź, Poland \\ * Correspondence: paulina.markowiak-kopec@edu.p.lodz.pl (P.M.-K.); katarzyna.slizewska@p.lodz.pl (K.Ś.); \\ Tel.: +48-42-6313-270 (P.M.-K. \& K.Ś.)
}

Received: 16 March 2020; Accepted: 13 April 2020; Published: 16 April 2020

\begin{abstract}
The relationship between diet and the diversity and function of the intestinal microbiome and its importance for human health is currently the subject of many studies. The type and proportion of microorganisms found in the intestines can determine the energy balance of the host. Intestinal microorganisms perform many important functions, one of which is participation in metabolic processes, e.g., in the production of short-chain fatty acids-SCFAs (also called volatile fatty acids). These acids represent the main carbon flow from the diet to the host microbiome. Maintaining intestinal balance is necessary to maintain the host's normal health and prevent many diseases. The results of many studies confirm the beneficial effect of probiotic microorganisms on the balance of the intestinal microbiome and produced metabolites, including SCFAs. The aim of this review is to summarize what is known on the effects of probiotics on the production of short-chain fatty acids by gut microbes. In addition, the mechanism of formation and properties of these metabolites is discussed and verified test results confirming the effectiveness of probiotics in human nutrition by modulating SCFAs production by intestinal microbiome is presented.
\end{abstract}

Keywords: probiotics; human health; SCFA; intestinal microbiome; metabolites of bacteria

\section{Introduction}

The most attention in research on human microbiome is devoted to the analysis of the diversity of microorganisms present in the digestive system, especially in the intestines. This metagenome is often called the third main mammalian genome, in addition to the nuclear and mitochondrial genomes. Nutrient absorption and energy regulation depend on environmental and lifestyle factors (dietary habits, drug treatments, intestinal motility and stool frequency and consistency) as well as the bacteria commonly found in the gastrointestinal tract (referred to as the intestinal or gut microbiome). Among the about 60 phyla of bacteria currently known, only some are present in human intestines (e.g., Firmicutes, Bacteroides, Actinobacteria, Fusobacteria, Proteobacteria, Verrucomicrobia, Cyanobacteria, and Spirochaetes) [1]. Two bacterial phyla, Gram-positive Firmicutes (Lactobacillus spp., Bacillus spp., and Clostridium spp.) and Gram-negative Bacteroidetes, predominate in human gut [2].

The type and proportions of microorganisms found in the intestines, i.e., the enterotype may determine the host's energy balance. In addition, the intestinal microbiome supports the biotransformation of numerous chemical compounds. Due to their metabolic abilities, intestinal microorganisms enable the transformation of complex nutrients, such as plant cell wall components (cellulose, pectin, hemicellulose, lignin) and mucins into simple sugars that are fermented to form short-chain fatty acids (SCFAs, mainly acetate, propionate and butyrate) [1]. The intestinal microbiome 
also plays an important role in modulating mucosal homeostasis of immune cell subpopulations and the synthesis of certain vitamins [3-6]. The activity of microorganisms in the intestines has a significant effect on the action of gastrointestinal hormones, maintaining intestinal homeostasis, regulates the proliferation and differentiation of epithelial cells, and prevents mucosal colonization by pathogenic microorganisms [7-9].

An imbalance of the intestinal microbiome and a decrease in the number of bacteria producing metabolites such as SCFAs (e.g., acetic, propionic and butyric acid) often occur in patients with inflammatory bowel diseases (IBD), irritable bowel syndrome (IBS), type 2 diabetes (T2D), obesity, autoimmune disorders or in cancer patients [10-14]. A lower abundance of specific bacteria and SCFAs leading to gut barrier dysfunction, low-grade inflammation and altered glucose, lipid and energy homeostasis are characteristic for obesity and T2D [15]. The composition of the intestinal microbiota was found to be different in people with obesity than in people of normal weight [16]. This is confirmed, among others, by studies in which Faecalibacterium prausnitzii was found to be the most abundant (about $5 \%$ of the bacterial population) in the intestines of healthy adults, while overweight people had a higher number of Firmicutes and Actinobacteria and a lower number of Bacteroidetes, Verrucomicrobia and F. prausnitzii [17]. Thus, research results indicate that obesity is associated with a decrease in the number of Bacteroidetes and an increase in the number of Firmicutes, with the intestinal microbiome of an obese person being less diverse than that of a lean person [18,19]. It should also be noted that Faecalibacterium prausnitzii is the first anti-inflammatory commensal bacterium identified on the basis of human clinical data and is also one of the major butyrate-producer of the human intestinal microbiome [20,21]. Other studies have shown a higher concentration of SCFAs (especially butyric and propionic acid) in the feces of overweight children compared to healthy children [2]. Similar results were obtained in a study of Swiss children, in this case the concentration of butyric and propionic acid was also significantly higher in the feces of overweight children [22]. However, different results were obtained for overweight Japanese and Mexican children, where SCFAs concentration was higher in the feces of children with normal weight $[23,24]$. Therefore, the trend of SCFAs content in feces cannot be dependent on a specific BMI group. Instead, the concentration of these acids is more associated with dysbiosis of the intestinal microbiome, genetics, environmental factors and diet [2].

There are many methods for modulating the intestinal microbiome. One of these is the use of probiotics, which can be helpful in maintaining or restoring homeostasis in the intestines to improve human health and prevent many diseases. According to the definition formulated in 2002 by the FAO (Food and Agriculture Organization of the United Nations, Rome, Italy) and the WHO (World Health Organization, Geneva, Switzerland), probiotics are live microorganisms which, when administered in adequate amounts, confer a health benefit on the host [25]. The definition was maintained by the International Scientific Association for Probiotics and Prebiotics (ISAPP) in 2013 and is still currently used [26]. The most commonly used probiotics are lactic acid bacteria (LAB) and bifidobacteria [8]. The growth and metabolic activity of probiotic microorganisms can be selectively stimulated by various types of carbohydrates that are not digested by the host (prebiotics) [9]. The combinations of probiotics with prebiotics (called synbiotics) are able to shift the predominant bacteria and the production of SCFAs of fecal microorganisms in a model system of the human colon [27].

\section{Short-Chain Fatty Acids}

Organic acids, principally the short-chain fatty acids (SCFAs) are formed in the GI tract in millimolar quantities and especially occur in high amounts in those areas where anaerobic microorganisms are predominant. SCFAs are volatile saturated fatty acids that have in their chain 1-6 carbon atoms in the aliphatic chain, existing in a straight or branched conformation [28]. In this review, attention has been focused on SCFAs with a simple conformation, which include formic, acetic, propionic, butyric, valerian, and caproic acids (Table 1). 
Table 1. Chemical and structural formulas of short-chain fatty acids (SCFAs) [29].

\begin{tabular}{|c|c|c|c|}
\hline Name & Chemical Formula & Structural Formula & Molar Mass [g/mol] \\
\hline Formic acid & $\mathrm{HCOOH}$ & & 46.03 \\
\hline Acetic acid & $\mathrm{CH}_{3} \mathrm{COOH}$ & & 60.05 \\
\hline Propionic acid & $\mathrm{CH}_{3} \mathrm{CH}_{2} \mathrm{COOH}$ & & 74.08 \\
\hline Butyric acid & $\mathrm{CH}_{3}\left(\mathrm{CH}_{2}\right)_{2} \mathrm{COOH}$ & & 88.11 \\
\hline Valeric acid & $\mathrm{CH}_{3}\left(\mathrm{CH}_{2}\right)_{3} \mathrm{COOH}$ & & 102.13 \\
\hline Caproic acid & $\mathrm{CH}_{3}\left(\mathrm{CH}_{2}\right)_{4} \mathrm{COOH}$ & & 116.16 \\
\hline
\end{tabular}

SCFAs represent the main carbon flow from the diet to the host microbiome [30]. The formation of these acids is relatively well-known and described [31,32]. The concentration and ratio of resulting SCFAs depend not only on the composition of the microbiome and the number of individual microorganisms in the colon, but also on the type of dietary fibers supplied to the microorganisms as a substrate in the fermentation process, and thus on the diet [8]. The most common are acetic acid, propionic acid and butyric acid (in a 3:1:1 molar ratio), which constitute 90\%-95\% of SCFAs present in the human colon, while a smaller proportion of these is formic acid [28].

In addition, the fermentation of selected, often rapidly fermentable non-digestible carbohydrates (NDCs) produces another organic acid-lactic acid [30]. Although it does not belong to the group of SCFAs, this acid can be produced by lactic acid bacteria, e.g., the genera Lactobacillus and Bifidobacterium [32]. However, under normal conditions it is not accumulated in the colon due to the presence of some bacterial species, e.g., Eubacterium hallii, that can convert lactate into different SCFAs [32]. Metagenomic analyses have greatly facilitated the identification of the types of bacteria responsible for the production of SCFAs and lactic acid (Table 2). 
Table 2. Examples of commensal and probiotic microorganisms producing SCFAs and lactic acid [5].

\begin{tabular}{|c|c|c|c|}
\hline Microorganism/s & Type & Acid/s & References \\
\hline $\begin{array}{c}\text { Bifidobacterium spp., Blautia hydrogentrophica, } \\
\text { Prevotella spp., Streptococcus spp. }\end{array}$ & commensal & acetic & [33] \\
\hline Akkermansia muciniphilia, Bacteroides spp. & commensal & acetic, propionic & {$[33,34]$} \\
\hline $\begin{array}{l}\text { Dalister succinatiphilus, Eubacterium spp. } \\
\text { (e.g., E. halli), Megasphaera elsdenii, } \\
\text { Phascolarctobacterium succinatutens, } \\
\text { Roseburia spp., Salmonella spp., Veillonella spp. }\end{array}$ & commensal & propionic & [34] \\
\hline $\begin{array}{c}\text { Coprococcus spp. (e.g., Coprococcus catus), } \\
\text { Roseburia inulinivorans }\end{array}$ & commensal & propionic, butyric & [34-36] \\
\hline $\begin{array}{c}\text { Anaerostipes spp., Coprococcus comes, Coprococcus } \\
\text { eutactus, Clostridium symbiosum, Eubacterium } \\
\text { rectale, Eubacterium hallii, Faecalibacterium spp. } \\
\text { (e.g., Faecalibacterium prausnitzii), Roseburia spp. } \\
\text { (e.g., Roseburia intestinalis) }\end{array}$ & commensal & butyric & [33-36] \\
\hline Clostridium spp., Ruminococcus spp. & commensal & acetic, propionic, butyric & {$[33,34,36,37]$} \\
\hline Bifidobacterium spp. & probiotic & acetic, lactic & [38] \\
\hline $\begin{array}{l}\text { Lactobacillus rhamnosus GG (LGG), } \\
\text { Lactobacillus gasseri PA 16/8 }\end{array}$ & probiotic & propionic, lactic & \multirow{2}{*}{ [5] } \\
\hline $\begin{array}{l}\text { Bifidobacterium longum SP 07/3, } \\
\text { Bifidobacterium bifidum MF 20/5 }\end{array}$ & probiotic & acetic, propionic, lactic & \\
\hline $\begin{array}{c}\text { Lactobacillus salivarius spp salcinius JCM 1230, } \\
\text { Lactobacillus agilis JCM } 1048\end{array}$ & probiotic & propionic, butyric, lactic & [39] \\
\hline Lactobacillus acidophilus CRL 1014 & probiotic & acetic, propionic, butyric, lactic & [40-43] \\
\hline
\end{tabular}

\subsection{Bacterial Fermentation Involved into Production of SCFAs}

Endogenous short-chain fatty acids are formed by bacterial fermentation of food fiber and NDCs, which become available to intestinal microorganisms in the large intestine. In addition to resistant starch (RS), plant-derived NDCs include non-starch polysaccharides (NSP), oligosaccharides (prebiotics), oligofructose, disaccharides (lactose, stachyose, raffinose) and monosaccharides e.g., alcohols (sorbitol, mannitol) [7]. There are four types of resistant starch (RS1-RS4) present in the human diet that are resistant to degradation in the small intestine [44,45]. The type of RS has a significant effect on the composition of the intestinal microbiome [46]. In the case of oligosaccharides, particularly important are prebiotics defined as a nonviable food component that confers a health benefit on the host associated with modulation of the microbiota [47]. However, endogenous indigestible carbohydrates include mucin and milk oligosaccharides [7].

Fermentation is an anaerobic redox process in the cytoplasm in which organic compounds are both electron donors and acceptors. In the fermentation process, electrons detached from the oxidized substrate are transferred by NADH directly to the endogenous acceptor. ATP is formed as a result of substrate phosphorylation, with the participation of the corresponding phosphoglycerate, pyruvate, acetate or butyrate kinases. During carbohydrate fermentation, the final electron acceptor is pyruvate or the compounds that are produced from it. The end products of fermentation are various short chain carboxylic acids (e.g., formic, acetic, lactic, butyric, propionic), $\mathrm{CO}_{2}, \mathrm{H}_{2}$, ethanol, glycerol, acetoin, 2,3-butanediol. Importantly, bacterial growth in populations mixed with other microorganisms can affect the type and amount of products produced during fermentation. The substrates most commonly used by microorganisms in the fermentation process are hexoses and pentoses [1].

Bacteria have a variety of pathways to transform sugars. These sugars are first phosphorylated and then in glycolysis (Embden-Meyerhof-Parnassian pathway), in the Entner-Doudoroff pathway or in the Bifidobacterium pathway are transformed into pyruvate or into pyruvate and additional acetyl-phosphate. The Embden-Meyerhof-Parnassian pathway, the major colonic pathway for the catabolism of hexoses, 
occurs in enterobacteria, clostridia, homofermentative lactic acid bacteria, and propionibacteria, and produces only pyruvate as a partial oxidation product) [48]. The Entner-Doudoroff pathway is used in the fermentation metabolism by e.g., Zymomonas (alcoholic fermentation), as well as Escherichia coli in gluconate fermentation. The Bifidobacterium pathway is active in bacteria of the genus Bifidobacterium, inhabiting, among others, the human digestive system. Two acetate molecules and one lactate are formed in this pathway. In the phosphoketolase pathway that occurs in heterofermentative lactic acid bacteria or the Bifidobacterium pathway, an additional molecule of acetyl-phosphate is generated (Figure 1) [49].

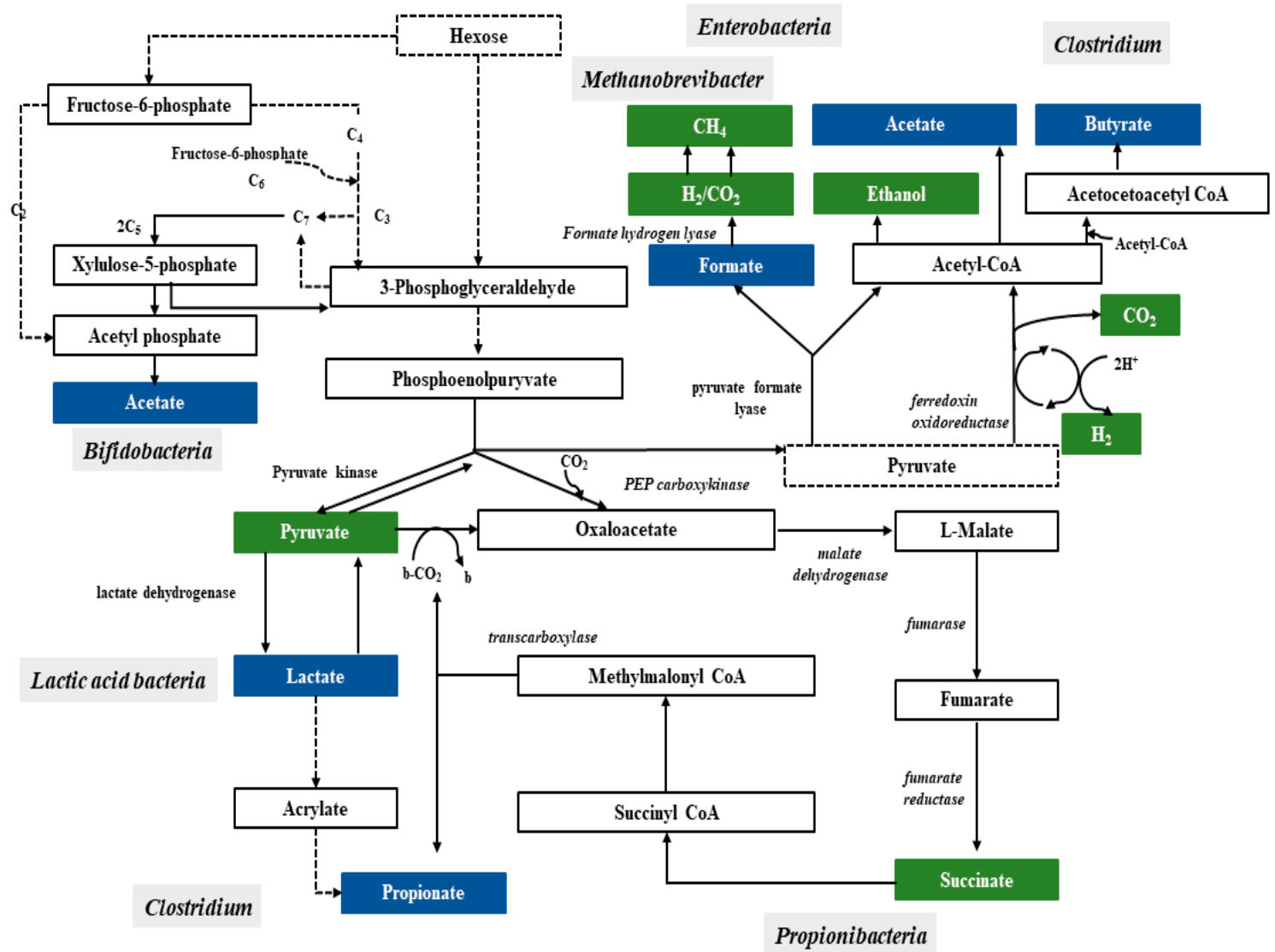

Figure 1. Pathways leading to SCFAs and lactic acid production by intestinal bacteria [48].

In a mixed population such as the intestinal microbiome, carbohydrate breakdown into a mixture of acids involves more than one species. This type of fermentation is called mixed acid fermentation or Enterobacteriaceae fermentation and is carried out by some bacteria belonging to this family, including Escherichia, Proteus, Salmonella, and Shigella [1]. The fermentation products of some species are substrates for fermentation or incorporated as intermediate metabolites into the metabolic pathways of other species, resulting in substrates being sequentially fermented. Lactate, ethanol, and pyruvate are diminished by subsequent bacterial utilization and SCFAs production. Accordingly, the main final products of sugar catabolism are SCFAs, acetate, propionate and butyrate that account for $85 \%-95 \%$ of total SCFAs in all regions of the colon. Other fermentation end products, such as caproate and valerate, occur in lower amounts [48].

Acetic acid is the most abundant SCFAs in the colon, accounting for more than half of the total SCFAs found in feces [49]. Intestinal microorganisms can produce acetic acid through two major metabolic processes. Most often it is fermentation of indigestible carbohydrates, while about $1 / 3$ of acetic acid is formed as a result of synthesis from hydrogen and carbon dioxide or formic acid by acetogenic bacteria through the Wood-Ljungdahl pathway [31,35]. 
Some types of Clostridium (C. acetobutylicum, C. butyricum, C. pasteurianum, C. perfringens) participate in butyric fermentation, as well as e.g., Butyrivibrio fibrisolvens and Fusobacterium nucleatum. The end products are butyric acid, a small amount of acetic acid and $\mathrm{CO}_{2}$ and $\mathrm{H}_{2}$. Some species may also form lactic acid and/or ethanol as well.

For propionic fermentation, the main substrates are glucose and lactate. Its course varies depending on the bacteria; it can occur that it forms succinate or acrylate [1].

Bacteria are capable of fermenting sugar degradation products (glycerol, citrate, malate, succinate, pyruvate, lactate, ethanol, acetate), and a small share of dietary protein fermentation processes in the production of SCFAs has been shown, mainly in the form of acetic and propionic acid [50]. Bacteria of the genus Clostridium are capable of fermenting amino acids. In this process, carbon dioxide, hydrogen, acetate, as well as ammonia and butyrate may form, which have an unpleasant odor. In addition, amino acids such as valine, leucine and isoleucine resulting from the anaerobic breakdown of proteins can be converted into compounds with strong odor, such as isobutyric, isovaleric and hexanoic acids, as well as cadaverine, putrescine, other amines, and hydrogen sulfide and methylmercaptan [1]. Excessive accumulation of isobutyric acid and isovaleric acid indicates a malfunctioning fermentation and digestion processes. These are putrefactive acids, the increased production of which may be associated with an excess of unabsorbed amino acids or proteins reaching the intestines. The possibility of blood in the intestinal contents and the overly intensive development of pathogenic microbiota in the small intestine should also be taken into account, where access to protein compounds is facilitated [51].

\subsection{Functions of Short-Chain Fatty Acids}

SCFAs have been shown to have a very positive effect on the energy metabolism of mammals that use them together with glucose as a metabolic fuel [52]. It has been estimated that the use of SCFAs as an energy source can provide up to $10 \%$ of the host's daily calories [53]. The presence of these acids in the human body, mainly acetic, butyric and propionic acids in sufficient quantities is essential for the health and well-being of the host [5]. However, the production of these acids requires the presence of appropriate substrates (dietary fiber and prebiotics) needed for the proper course of the fermentation processes.

SCFAs play a very important role in maintaining intestinal and immune homeostasis in the human body (Figure 2). 


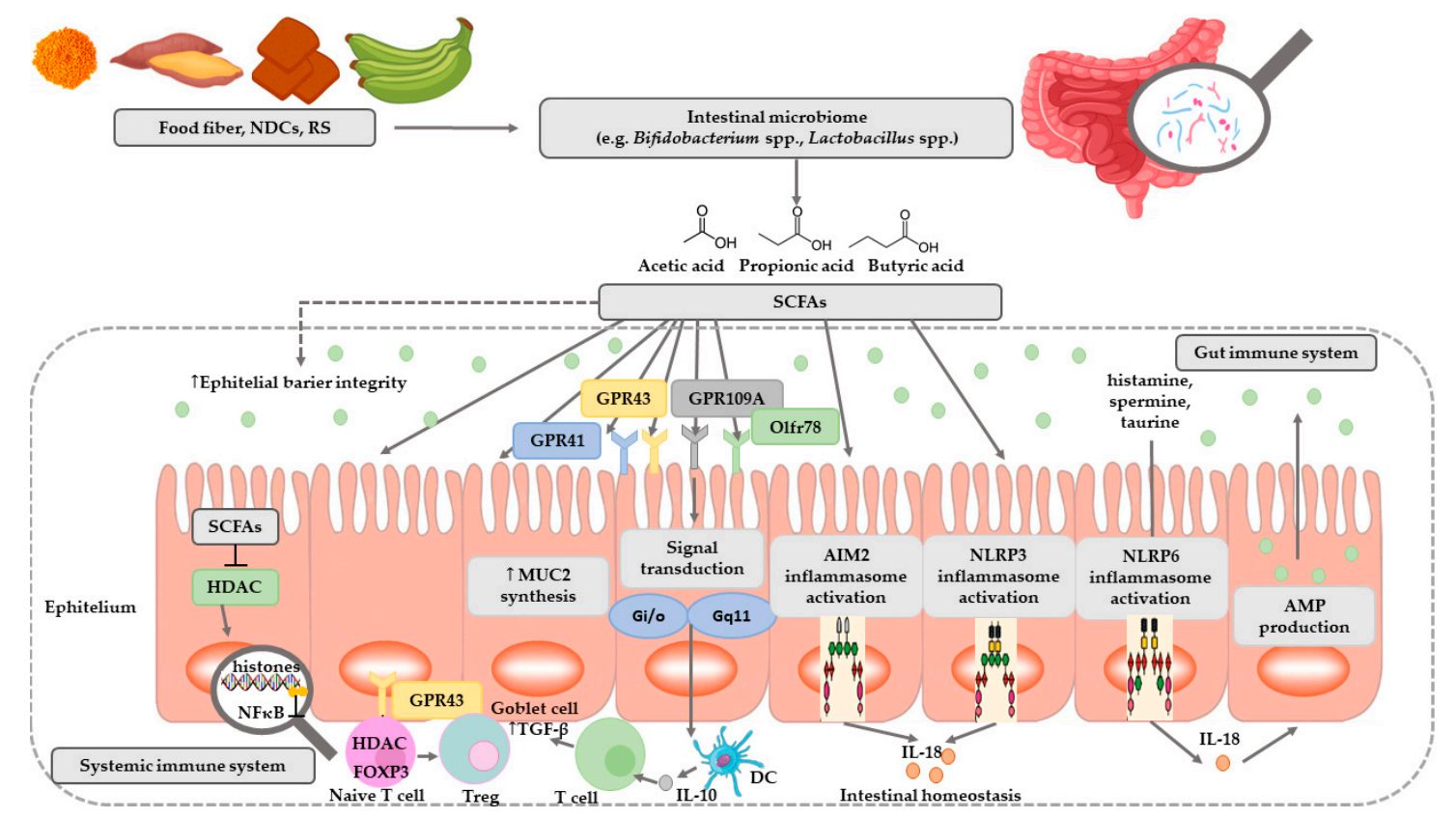

Figure 2. The role of SCFAs in regulation of intestinal homeostasis. SCFAs (acetic, propionic, and butyric acid) are produced by intestinal microbiome in fermentation of undigested food fiber, non-digestible carbohydrates (NDCs) or resistant starch (RS). SCFAs are as energy substrates for colonocytes and regulate intestinal barrier function (synthesis of mucin-MUC2) and immune system through G-protein-coupled receptors (GPR41, GPR43, GPR109A) and Olfr78 receptor signaling. SCFAs regulate the histone deacetylase (HDAC) activity which affects inhibition of nuclear factors (nuclear factor- $\kappa \mathrm{B} ; \mathrm{NF}-\kappa \mathrm{B})$. SCFAs affect the differentiation of regulatory $\mathrm{T}$ (Treg) cells and the production of interleukin-10 (IL-10) with the participation of GPR43. SCFAs also regulate dendritic cell (DC) function. In addition, SCFAs influence AIM2 and NLRP3 inflammasomes activation which then affects production of interleukin-18 (IL-18) and enhanced epithelial barrier function. Moreover, NLRP6 inflammasome activation and secretion of IL-18 regulate the production of intestinal antimicrobial peptides (AMPs) [54,55]. Abbreviations: FOXP3-forkhead box P3; TGF- $\beta$-transforming growth factor $\beta$.

SCFAs are speculated to have a mediational role in the microbiota-gut-brain axis crosstalk [56]. Two major SCFAs signaling mechanisms have been identified, namely inhibition of HDACs and activation of GPCRs_-The binding partners of GPR41 and GPR43 (Table 3) [57,58]. 
Table 3. The characteristics of SCFAs and lactic acid receptors [33,59-61].

\begin{tabular}{|c|c|c|c|c|}
\hline Receptor & Ligand & Protein G & Exspression & Physiological Function \\
\hline $\begin{array}{l}\text { FFAR2-Free fatty acid } \\
\text { receptor } 2 \text { (GPR43) }\end{array}$ & $\begin{array}{c}\text { Acetate, } \\
\text { propionate, butyrate }\end{array}$ & $\mathrm{Gi} / \mathrm{o}, \mathrm{Gq} 11$ & $\begin{array}{l}\text { Small intestinal epithelium, colonic, colonic } \\
\text { LP cells, leukocytes in small intestinal LP, } \\
\text { adipocytes, polymorphonuclear cells, } \\
\text { skeltal muscle, spleen and heart etc. }\end{array}$ & $\begin{array}{l}\text { Apetite control, anti-lipolysis, increased insulin } \\
\text { sensitivity, preadipocyte differentiation, } \\
\text { expansion and differentiation of Tregs, } \\
\text { protection against IBD, apoptosis of human } \\
\text { colon cancer cel line etc. }\end{array}$ \\
\hline $\begin{array}{l}\text { FFAR3-Free fatty acid } \\
\text { receptor } 3 \text { (GPR41) }\end{array}$ & $\begin{array}{c}\text { Acetate, } \\
\text { propionate, butyrate }\end{array}$ & $\mathrm{Gi} / \mathrm{o}$ & $\begin{array}{l}\text { Small intestinal epithelium, colonic, colonic } \\
\text { LP cells (mast cells), peripheral nervous } \\
\text { system, peripheral mononuclear cells, bone } \\
\text { marrow spleen, adipocytes, lymph } \\
\text { nodes, etc. }\end{array}$ & $\begin{array}{l}\text { Leptin expression, oxygen consumption rate, } \\
\text { increased energy expenditure, decreased food } \\
\text { intake, hematopoiesis of DCs from bone marrow, } \\
\text { increased DC precursors alleviating asthma and } \\
\text { Treg cells etc. }\end{array}$ \\
\hline $\begin{array}{l}\text { HCA1-Hydroxycarboxylic } \\
\text { acid receptor } 1 \text { (GPR81) }\end{array}$ & lactate & $(\mathrm{Gi})$ & $\begin{array}{l}\text { Predominantly in adipose tissue, minor in } \\
\text { kidney, skeletal muscle, liver, intestinal } \\
\text { tissue, rat and human brain, mouse } \\
\text { primary cortical neuronal cells, } \\
\text { macrophages, etc. }\end{array}$ & $\begin{array}{l}\text { Modulation of cortical neuron activity, and } \\
\text { enterocyte turnover in response to } \\
\text { starvation-refeeding, anti-lipolysis, } \\
\text { anti-inflammatory on macrophages, reduced } \\
\text { symptom of cancer and IBD in mouse models of } \\
\text { hepatitis and pancreatitis, etc. }\end{array}$ \\
\hline $\begin{array}{l}\text { HCA2-Hydroxycarboxylic } \\
\text { acid receptor } 2 \text { (GPR109A) }\end{array}$ & $\begin{array}{l}\text { Niacin, ketone } \\
\text { bodies, } \\
\beta \text {-hydroxybutyric } \\
\text { acids, butyrate }\end{array}$ & $\mathrm{Gi} / \mathrm{o}, \mathrm{G} \beta \gamma$ & $\begin{array}{l}\text { Apical membrane of colonic and small } \\
\text { intestinal epithelium, monocytes, } \\
\text { adipocytes, macrophages, DCs, neutrophils, } \\
\text { retinal pigment epithelium, etc. }\end{array}$ & $\begin{array}{l}\text { Improved epithelial barrier function, } \\
\text { anti-lipolysis, decrease of triglyceride, protection } \\
\text { against CRC and colitis, increase of Treg } \\
\text { generation and IL-10 producing T cells, etc. }\end{array}$ \\
\hline $\begin{array}{l}\text { Olfr78 (murine) } \\
\text { OR51E2 (human) }\end{array}$ & Acetate, propionate & NR & $\begin{array}{l}\text { Neurons, epithelial enteroendocrine cells of } \\
\text { colon, enteroendocrine cells, renal afferent } \\
\text { arteriole, smooth muscle cells, etc. }\end{array}$ & $\begin{array}{l}\text { Regulation of hormone secretion (GLP-1, PYY) } \\
\text { and blood pressure, etc. }\end{array}$ \\
\hline $\begin{array}{l}\text { PPAR } \gamma \text { (Peroxisome } \\
\text { proliferator-activated } \\
\text { receptor gamma) }\end{array}$ & Propionate, butyrate & NR & Large intestine adenocarcinoma cells, etc. & $\begin{array}{l}\text { Regulation of lipid metabolism, a joining factor } \\
\text { between the gut microflora composition and } \\
\text { accumulation of the adipose tissue, etc. }\end{array}$ \\
\hline
\end{tabular}

Abbreviations: CRC—colorectal cancer; DC—dendritic cell; GLP-1, glucagon-like peptide; GPR—G-protein coupled receptor; IBD—inflammatory bowel disease; IL-10 (interleukin-10);

LP—lamina propria; NR—not reported; Olfr-olfactory receptor; PYY—peptide YY; Treg-regulatory T cell. 
SCFAs play a very important role in regulating $\mathrm{pH}$, increasing the absorption of calcium, iron, as well as magnesium, and are beneficial for glucose and protein metabolism in the liver. In addition, these acids affect the maintenance of the normal structure, integrity and function of the intestines [7]. They show anti-inflammatory activity, which involves inhibiting the activity of inflammatory mediators in the intestinal epithelium, and thus inhibiting the activation of NFkB macrophages, which are the main source of cytokines in the course of the inflammatory process of inflammatory bowel diseases [7]. These acids are the primary source of energy for colonocytes $[62,63]$. It has been shown that the source of $70 \%$ of the energy used by intestinal epithelial cells (IEC) is butyric acid produced by commensal bacteria, especially such as Ruminococcus and Faecalibacterium (Table 4) [37]. In addition, by simulating the growth of saprophytic microflora, SCFAs inhibit the development of pathogenic microorganisms such as Escherichia coli, Salmonella, or Campylobacter, competing for colonization sites [8]. Studies have shown that butyric acid stimulates the expression of the MUC2 gene in cell lines and the production of mucin, and the sticky layer it creates protects the intestinal epithelium from contact with toxins and pathogenic microorganisms [64]. In contrast, studies of programmed cell death from a tumor line have demonstrated the effectiveness of butyric acid in inhibiting their development and inducing the process of apoptosis [65-67]. In addition, butyric acid and propionic, acetic, and valeric acids have been shown to induce apoptosis (Table 4) [68].

SCFAs increase the amount of mucus produced and the speed of blood flow. More importantly, they provide acetyl-CoA used in the process of fat biosynthesis and cell membrane production, guaranteeing the integrity of mucous membranes [69]. There are indications that SCFAs are key mediators of the beneficial effects of intestinal microbiota. SCFAs also directly modulate host health through a number of tissue-specific mechanisms associated with intestinal barrier function, glucose homeostasis, immunomodulation, appetite regulation, obesity, and have a direct and indirect effect on cardiovascular disease (CVD) risk markers [70].

At present, relatively little is known about the function of formic acid in the intestines. There are indications that its presence is associated with methanogenesis and its concentration may be elevated during inflammation (Table 4) [71,72]. Acetic acid concentration in the colon is the highest of all SCFAs, and in cells it is a key factor in the metabolism of carbohydrates and fats [73]. In addition, acetic acid is absorbed by the liver, where it participates in the synthesis of cholesterol (Table 4) [74]. Propionic acid is produced in the human gut mainly by Bacteroidetes and Firmicutes [75]. This acid is an inhibitor of gluconeogenesis and cholesterol synthesis in the liver [76]. In addition, it has antibacterial and anti-inflammatory effects, taking part in the protection of human intestines against pathogens $[8,77]$. Butyric acid exerts the strongest anti-inflammatory effect of all SCFAs [7]. The cause of the inflammatory process of the intestinal mucosa, which accompanies many pathological processes, is a lack of energy. Butyric acid is the main source of energy for intestinal epithelial cells. Butyric acid has a beneficial immunoregulatory effect on intestinal epithelial cells and other mucosal cell populations. It modulates gene expression by affecting both stimulants and inhibitors of expression. Some of these mechanisms are based on histone hyperacetylation due to inhibition of the histone deacetylase enzyme activity (Table 4) [78].

Unlike other SCFAs, the role of valeric acid in gut health is not fully understood. In a limited number of studies, it was found that valeric acid can stimulate the growth of intestinal epithelium and have a beneficial effect on the pathogenesis of diseases such as colitis, cardio-metabolic diseases and cancer (Table 4) [79-81]. 
Table 4. Examples of trials regarding the effect of SCFAs on human health.

\begin{tabular}{|c|c|c|}
\hline Type of SCFA & The Effect on Human Health & References \\
\hline \multirow{2}{*}{ Acetate } & - $\quad$ Protection against E. coli O157:H7 infection & [82] \\
\hline & - $\quad$ Participates in the synthesis of cholesterol & [74] \\
\hline \multirow{7}{*}{ Butyrate } & - Is the source of $70 \%$ of the energy used by intestinal epithelial cells & [37] \\
\hline & - Increases in MUC2 gene expression and the production of mucin & {$[64]$} \\
\hline & $\begin{array}{l}\text { inhibits development of tumor cells and inducing the process of } \\
\text { their apoptosis }\end{array}$ & [65-67] \\
\hline & $\begin{array}{l}\text { Inhibits the genotoxic activity of nitrosamides and } \\
\text { hydrogen peroxide }\end{array}$ & [83] \\
\hline & - Has immunoregulatory effect & [78] \\
\hline & $\begin{array}{l}\text { Plays a role in the prevention and the treatment of distal ulcerative } \\
\text { colitis, Crohn's disease and cancer }\end{array}$ & [84] \\
\hline & - Improves ulcerative colitis (UC) symptoms & [85] \\
\hline $\begin{array}{l}\text { Butyrate/ } \\
\text { acetate/propionate }\end{array}$ & - Improves the macroscopic and histological signs of inflammation & [86] \\
\hline Formate & $\begin{array}{l}\text { - Presence is associated with methanogenesis and its concentration } \\
\text { may be elevated during inflammation }\end{array}$ & {$[71,72]$} \\
\hline \multirow[t]{2}{*}{ Propionate } & $\begin{array}{l}\text { - Decreases cholesterol synthesis in the liver, improves } \\
\text { lipid metabolism }\end{array}$ & {$[76,87]$} \\
\hline & - Has anti-proliferative effect & {$[88,89]$} \\
\hline Valerate & $\begin{array}{l}\text { - Stimulates the growth of intestinal epithelium } \\
\text { - Has a beneficial effect on the pathogenesis of diseases such as } \\
\text { colitis, cardio-metabolic diseases and cancer }\end{array}$ & [79-81] \\
\hline
\end{tabular}

\section{The Effect of Probiotics on SCFAs Production by Intestinal Microbiome}

In order to determine the effect of probiotics on the SCFA production to human intestinal microbiome of a literature review was conducted using the database Web of Science, Medline, Elsevier. To identify relevant studies, articles from 1996 to 2020 in databases were searched. The following keywords were used in the search: Probiotic, SCFA, colorectal cancer, obesity, diabetes, type 2 diabetes, atopic dermatitis, autism spectrum disorders, cardiovascular disease, gastrointestinal disorders, etc. The search was restricted to publications in English. A comprehensive full-text review of identified studies was conducted after the title and abstract screening of potentially relevant articles.

Intestinal microorganisms, due to their participation in metabolic processes, have a significant impact on the metabolism of the whole body. The balance of this microbiome is necessary to maintain the proper health of the host and prevent many diseases. Therefore, researchers hypothesized that in people in whom the number of certain groups of microorganisms is too low, deliberate reproduction or administration of these microorganisms may be beneficial [90].

In in vitro human intestinal model studies (the M-SHIME ${ }^{\circledR}$ system), effect of an aqueous probiotic suspension (Symprove ${ }^{\mathrm{TM}}$, containing Lactobacillus acidophilus NCIMB 30175, Lactobacillus plantarum NCIMB 30173, Lactobacillus rhamnosus NCIMB 30174, and Enterococcus faecium NCIMB 30176) on bacterial diversity was tested. SCFAs production and inflammatory markers after 3 weeks dosing of probiotic was found [91]. The results confirmed colonization and growth of three probiotic species in the luminal and mucosal compartments of the proximal and distal colon, and growth of a last species in the luminal proximal colon. The colonization and growth probiotic bacteria leaded to higher proximal and distal colonic lactate concentrations. In effect, the lactate stimulated growth of lactate-consuming bacteria and resulting in increased SCFAs production, especially butyrate. Additionally, an immunomodulatory effect of the probiotics was seen; production of anti-inflammatory 
cytokines (IL-10 and IL-6) was increased and production of inflammatory chemokines (IL-8, CXCL 10 and MCP-1 and) was reduced [91].

In another study, the effect of oral consumption of Lactobacillus plantarum P-8 (Lp-8) on human intestinal microflora, and SCFAs of different aged adults was tested [92]. 33 volunteers including young (mean age 26 years), middle-aged (mean age 51 years), and elderly (mean age 76 years) received Lp-8 $\left(6 \times 10^{10}\right.$ colony forming units daily) for 4 weeks. The increase in Bifidobacterium and other beneficial bacteria was found, whereas Desulfovibrio and other opportunistic pathogens decreased after taking probiotic for 4 weeks. A statistically significant increase in acetate and propionate levels in all age groups was found, which reached a peak after 5 weeks in all age groups [92].

Other scientists also tested the anti-aging potential of a probiotic in combination containing Lactobacillus paracasei ssp. paracasei BCRC 12188, Lactobacillus plantarum BCRC 12251, and Streptococcus thermophilus BCRC13869. The studies used the murine model in vivo, wherein the aging induced d-galactose [93]. The 12-week study was conducted on 15 mice. It turns out that long-term administration of the probiotic mixture by increasing the production of SCFAs (might regulate antioxidant enzymes by inducing expression of Nrf2 or HO-1) and inhibiting cell apoptosis and brain injury, resulting in improved memory and learning abilities in d-galactose-treated aging mice [93].

Moreover, in different research the potential health benefits of a fermented salami with a probiotic Lactobacillus rhamnosus HN001 and added citrus fiber for 4 weeks in 24 health people was tested [94]. It was found that the inflammatory markers CRP and TNF $\alpha$ decreased significantly after intervention, suggesting a less inflammatory environment after reformulated salami consumption. In addition, antioxidant plasmatic markers also improved and butyrate production was significantly increased within the intervention group [94].

\subsection{Colorectal Cancer (CRC)}

CRC is the third most prevalent cause of death among the different types of cancer and the highest incidence being in developed countries [95]. It is estimated that by 2035, 24.4 million new cases of CRC will be diagnosed annually [96]. CRC is strongly correlated with decreased levels of SCFAs and microbiome dysbiosis [95]. Administration of Butyrivibrio fibrisolvens MDT-1, (known for their high production of butyrate) in mouse model of colon cancer, inhibited progression of tumor development, affecting also the reduction of $\beta$-glucuronidase and increasing the immune response [97]. Currently, it is suggested to modulate SCFA-producing bacteria through dietary intervention with fermentable fibers as a possible treatment for CRC [98]. In many in vitro studies have attempted to determine effects and potential mechanisms of action of probiotics in the inhibition of cancer cell proliferation. In the research on human colonic cancer cell line Caco-2, Pediococcus pentosaceus FP3, Lactobacillus salivarius FP25 and FP35, and Enterococcus faecium FP51 in different concentrations were tested [99]. Tested probiotics reduced cell proliferation. Mechanisms responsible for this effect were adhesion of probiotic bacteria to colon cancer cells and an increase in bioproduction of SCFAs [99]. On the other hand, in the study on human colonic cancer cells lines HT-29 and Caco-2 with using skimmed milk kefir and ayran, antioxidant and SCFAs activities were recognized as mechanisms responsible for the beneficial effect of the probiotic [100]. In this case, beneficial effect of probiotics was associated with lowering genotoxicity of fecal water added to the medium [100]. Other studies also confirmed the beneficial effect of SCFAs. In the research on human colonic cancer cells lines HCT116, SW1116, and Caco-2, the effect and the mechanism of action Clostridium butyricum ATCC 23857 and Bacillus subtilis ATCC 19398 were analyzed [101]. A beneficial effect was the reduction of cell proliferation and expression of inflammatory genes as a result of the presence of bacitracin or butyrate in the conditioned medium induced cell cycle arrest and apoptosis activation [101]. In the studies on male rats F344 (5 weeks old) the effect of Lactobacillus salivarius was tested [102]. As a result of the decrease in azoreductase activity and the intestinal population of Bacillus and Ruminococcaceae while increasing the number of intestinal populations of Prevotella, Bacteroides, Lachnospiraceae, Clostridium, and the concentration of SCFAs in feces, a decrease in aberrant crypt foci (ACF) incidence was found [102]. As part of the 
randomized, double-blind, placebo-controlled research 10 colorectal cancer patients and 20 healthy subjects were receiving Lactobacillus gasseri OLL271 6: LG21 for 12 weeks [103]. The effect of the tested probiotic was increase number of Lactobacillus spp. and decrease number of Clostridium perfringens in intestinal population. Moreover, increase in concentration isobutyric acid in feces and natural killer (NK) cell activity were found. In addition, supplementation of probiotic caused a decrease in $\mathrm{pH}$ and the synthesis of fecal putrefaction products (Table 5) [103].

In another research, effect of Bifidobacterium lactis LAFTI B94 administration in 17 healthy subjects (aged 45 to 75 years) for 4 weeks was tested [104]. The treatment resulted increase number of Bifidobacterium lactis in intestinal population, but changes in the $\mathrm{pH}$, the SFCA fecal concentration, the serum hs-CRP and cytokines and also the crypt proliferation and cell height weren't found (Table 5) [104].

Table 5. Examples of clinical trials regarding the effect of probiotics on SCFAs production by human intestinal microbiota.

\begin{tabular}{|c|c|c|c|c|}
\hline Subjects & Probiotic & Time of Administration & Main Outcome & Ref. \\
\hline $\begin{array}{l}30 \text { patients (10 CRC } \\
\text { patients and } \\
20 \text { healthy subjects) }\end{array}$ & $\begin{array}{l}\text { Lactobacillus gasseri } \\
\text { OLL271 6: LG21 }\end{array}$ & 12 weeks & $\begin{array}{ll}\text { - } & \uparrow \text { number of Lactobacillus spp., } \\
& \downarrow \text { number of Clostridium } \\
& \text { perfringens in } \\
& \text { intestinal population; } \\
\text { - } & \uparrow \text { concentration isobutyric acid } \\
& \text { in feces and natural killer (NK) } \\
& \text { cell activity; } \\
\text { - } \quad \downarrow \text { pH and the synthesis of fecal } \\
\text { putrefaction products. }\end{array}$ & {$[103]$} \\
\hline $\begin{array}{l}17 \text { healthy subjects } \\
\text { (aged } 45 \text { to } 75 \text { years) }\end{array}$ & $\begin{array}{l}\text { Bifidobacterium } \\
\text { lactis LAFTI B94 }\end{array}$ & 4 weeks & $\begin{array}{l}\text { - } \uparrow \text { number of Bifidobacterium } \\
\text { lactis in intestinal population; } \\
\text { no changes in the } \mathrm{pH} \text {, the } \\
\text { SFCA fecal concentration, the } \\
\text { serum hs-CRP and cytokines } \\
\text { and also the crypt proliferation } \\
\text { and cell height. }\end{array}$ & [104] \\
\hline
\end{tabular}

\begin{tabular}{|c|c|c|c|c|}
\hline \multicolumn{5}{|c|}{ Obesity } \\
\hline $\begin{array}{l}40 \text { children } 7-10 \text { years } \\
\text { (19 normal weight and } \\
21 \text { overweight children) }\end{array}$ & $\begin{array}{c}\text { Lactobacillus casei } \\
\text { Shirota }\end{array}$ & $\begin{array}{c}2 \text { phases (each lasted for } \\
4 \text { weeks with a } 4 \text {-week } \\
\text { wash-out period } \\
\text { between phases) }\end{array}$ & $\begin{array}{l}\text { - } \quad \text { number of Lactobacillus spp. } \\
\text { and Bifidobacterium spp.; } \\
\text { - } \quad \text { the total SCFAs and } \\
\text { propionic acid contents in } \\
\text { normal weight and } \\
\text { overweight children. }\end{array}$ & {$[2]$} \\
\hline $\begin{array}{c}34 \text { children } \\
8.5-10.8 \text { years } \\
\text { (22 normal weight and } \\
12 \text { overweight } \\
\text { children) }\end{array}$ & $\begin{array}{c}\text { Lactobacillus casei } \\
\text { Shirota }\end{array}$ & 6 months & $\begin{array}{l}\text { - } \quad \downarrow \text { weight; } \\
\text { improving the lipid } \\
\text { metabolism in children } \\
\text { with obesity; } \\
\text { - } \quad \text { number of Bifidobacterium } \\
\text { spp. and the acetic acid } \\
\text { concentration in the feces. }\end{array}$ & {$[24]$} \\
\hline 50 volunteers with T2D & $\begin{array}{l}\text { Lactobacillus } \\
\text { acidophilus La-5, } \\
\text { Bifidobacterium } \\
\text { animalis subsp. } \\
\text { lactis BB-12 }\end{array}$ & 6 weeks & $\begin{array}{l}\text { the proportion of C3:C2:C4 } \\
\text { acids, taking into account the } \\
\text { mean values, was also similar: } \\
\text { 10:8:1 in the control group and } \\
\text { 14:10:1 in the probiotic group, } \\
\text { improving glycemic control. }\end{array}$ & {$[105]$} \\
\hline
\end{tabular}


Table 5. Cont.

\begin{tabular}{|c|c|c|c|c|}
\hline Subjects & Probiotic & Time of Administration & Main Outcome & Ref. \\
\hline $\begin{array}{l}22 \text { children with } \\
\text { shigellosis and } \\
11 \text { children with } \\
\text { salmonellosis } \\
\text { (mean age-5.3 years) }\end{array}$ & $\begin{array}{l}\text { Lactobacillus } \\
\text { rhamnosus GG } \\
\text { (ATCC 53103) }\end{array}$ & $\begin{array}{l}\text { In three portions per day } \\
\text { for } 10 \text { days compared to } \\
\text { treatment with an } \\
\text { antibacterial drug } \\
\text { (TMP-SMX or } \\
\text { Polymyxin) for } 5 \text { days. }\end{array}$ & $\begin{array}{l}\text { acetic, propionic and } \\
\text { iso-valeric acid were } \\
\text { significantly higher in } \\
\text { shigellosis than } \\
\text { in salmonellosis. } \\
\text { - concentration of propionic } \\
\text { acid by the 5th day } \\
\text { of treatment; } \\
\text { difference in iso-caproic acid in } \\
\text { the 10th day samples: it was } \\
\text { not found in any child who } \\
\text { had received probiotic but was } \\
\text { present in half of the samples } \\
\text { from the group treated solely } \\
\text { with antibacterial drug. }\end{array}$ & {$[106]$} \\
\hline \multicolumn{5}{|c|}{ Autism Spectrum Disorders } \\
\hline $\begin{array}{l}97 \text { children ( } 58 \text { children } \\
\text { with ASD-two groups: } \\
\text { A-Probiotic, } \\
\text { A-No-Probiotic and } \\
39 \text { healthy children) } \\
\text { (2.5-18 years) }\end{array}$ & & formation & $\begin{array}{l}\text { - } \quad \downarrow \text { level of acetate, propionate } \\
\text { and valerate and total SCFAs } \\
\text { in children with autism; } \\
\text { the imbalance of gut } \\
\text { microbiota in children } \\
\text { with autism. }\end{array}$ & [107] \\
\hline \multicolumn{5}{|c|}{ Atopic Dermatitis } \\
\hline $\begin{array}{l}19 \text { AD children and } 18 \\
\text { healthy individuals } \\
\text { (0-6 years) }\end{array}$ & $\begin{array}{l}\text { Bifidobacterium } \\
\text { breve BR03, } \\
\text { Lactobacillus } \\
\text { salivarius LS01 }\end{array}$ & 20 days & $\begin{array}{l}\text { an alteration in AD } \\
\text { microbiome composition with } \\
\text { the depletion or absence of } \\
\text { some species; } \\
\text { - } \quad \downarrow \text { SCFAs producing bacteria. }\end{array}$ & [108] \\
\hline
\end{tabular}

\subsection{Obesity}

Obesity is a risk factor for CVD, dyslipidemia, hepatobiliary disease diabetes, premature death, and several cancers. There is an estimate of 1.7 billion people in the world that are overweight [109]. Individuals with obesity usually have an altered composition of intestinal microbiome, which suggest that intestinal microbiome can be considered the factor that creates the development of obesity [110]. Changes in the composition of the intestinal microbiome can be associated with obesity through changes in the form of reduced activity of the fasting-induced adipose factor (FIAF) and AMP-activated protein kinase (AMK), reduced production of SCFAs, increased inflammation or altered LPS-endocannabinoid (eCB) system regulators loops, and bile acid metabolism [110]. The host's diet is considered to be the cause of these changes [109]. Manipulating microbial populations with probiotics in the presence of proper diets can reduce enteritis, improve intestinal barrier integrity, and increase the number of beneficial bacteria, which leads to weight loss [111]. Improvement of intestinal dysbiosis and obesity in animals and humans have been reported as a result of the use of probiotics $[112,113]$. However, animal studies still prevail, while there is little research on the effects of probiotics on SCFAs content in human feces. The administration of the probiotic strain Lactobacillus acidophilus DDS- 1 has been shown to modulate the intestinal microbiome and the associated metabolic phenotype in aging mice. Probiotic administration increased the number of beneficial bacteria such as Akkermansia spp. and Lactobacillus spp and also caused an increase in butyric acid concentration, while reducing the production of inflammatory cytokines in serum and colonic explants [114]. The results of many other animal studies indicate that supplementation with probiotic Lactobacillus spp. bacteria induced SCFAs production by modulation of the intestinal microbiome $[14,84,115,116]$. For example, the probiotic bacteria Bifidobacterium pseudocatenulatum CECT 7765 administered to rats that received high-fat diets had an effect on increasing the intestinal barrier function, reducing endotoxemia and accelerating 
metabolism [117,118]. Satisfactory results for Lactobacillus plantarum strain no. 14 on improving metabolism have been shown in studies on obesity in animal models [119]. Other studies tested the efficacy of probiotic VSL\#3 in preventing and treating obesity and diabetes in several mouse models [120]. It was confirmed that probiotic formula VSL\#3 suppressed body weight gain and insulin resistance via modulation of the gut flora composition. In addition, it was found that VSL\#3 promoted the release of the hormone GLP-1, resulting in reduced food intake and improved glucose tolerance. The VSL\#3-induced changes were associated with an increase in the levels of a short-chain fatty acid (SCFAs), butyrate [117]. In another study feces from 40 Malaysian school-age children (19 of normal weight and 21 overweight children) who consumed a probiotic drink containing the Lactobacillus casei Shirota strain in two stages (four weeks each) were examined [2]. It was found that the consumption of the probiotic drink caused a significant increase in the number of Lactobacillus spp. and Bifidobacterium spp. in the composition of intestinal microbiota of overweight children. Both in normal weight and overweight children after four weeks of supplementation, a significant increase in SCFAs concentration, especially of propionic acid, was observed. In addition, a higher SCFAs concentration (especially butyric and propionic acid) was observed in the stool of overweight children than in normal weight children (Table 5) [2]. Also, when Lactobacillus casei Shirota was administered to children with obesity for six months, there was an improvement in the profile of intestinal microbiota and an increase in the concentration of acetic acid in the faces of children with obesity (Table 5) [24].

\subsection{Type 2 Diabetes (T2D)}

Diabetes may be closely associated with a higher risk of CVD. This is due to the compensatory effect leading to hyperinsulinemia and ultimately to various metabolic abnormalities. People with diabetes are also characterized by an altered intestinal microbiome, which can cause obesity, metabolic endotoxemia, B-cell dysfunction, systemic inflammation, and oxidative stress related to disease [109]. As a result of intestinal microbiome imbalance in T2D, production of SCFAs is reduced [90]. Probiotic therapy due to the increased production of SCFAs by intestinal bacteria as well as other functions may be effective in the treatment of diabetes.

In the study on 60 mice for 6 weeks, the anti-diabetic mechanisms of probiotics composed of 14 strains (Lactobacillus plantarum, Lactobacillus helveticus, Lactococcus lactis, Lactobacillus pentosus, Lactobacillus paracasei, Lactobacillus paracasei sbusp.tolerans, Lactobacillus mucosae, Lactobacillus rhamnosus, Lactobacillus harbinensis and Lactobacillus hilgardii, Issatchenkia orientalis, Candida ethanolica, Kluyveromyces marxianus, Pichia membranifaciens) isolated from traditional fermented camel milk was tested [121]. It was found that tested probiotics improve blood glucose and blood lipid parameters, which can lead to delayed development of T2D. In addition, these probiotics improve the function of the intestinal microbiome by increasing the levels of SCFA-producing bacteria (including lactic acid bacteria, Bifidobacterium, Clostridium leptum, Roseburia) and SCFAs (propionic acid and butyric acid) as well as the expression of cluaudin-1 and mucin -2, and decreasing Escherichia coli and lipopolysaccharide levels. The results obtained in these studies indicated that 14 composite probiotics might be considered to be a potential treatment method for treating patients with T2D [121].

The aim of other studies was to determine the effect of probiotic (fermented goat's milk containing Lactobacillus acidophilus La-5 and Bifidobacterium animalis subsp. lactis BB-12) on glycemic control, lipid profile, inflammation, oxidative stress and SCFAs in T2D [105]. In a double-blind, randomized, placebo-controlled trial 50 volunteers consumed daily $120 \mathrm{~g} / \mathrm{d}$ of fermented milk for 6 weeks. The control sample was the group receiving conventional fermented goat milk contained Streptococcus thermophilus TA-40. At end of trial, the proportion of propionic: acetic: butyric acids, taking into account the mean values, was also similar: 10:8:1 in the control group and 14:10:1 in the probiotic group. The authors found that administration of the test probiotic improves glycemic control in people with T2D, however, the intake of fermented goat's milk seems to be involved with changes in inflammatory cytokines (TNF- $\alpha$ and resistin) and in the acetic acid concentrations (Table 5) [105]. 


\subsection{Cardiovascular Disease (CVD)}

CVD is the main cause of morbidity and mortality in the world, there is currently a search for methods of treating elevated blood cholesterol. Researchers suggest that high-fat diet consumption has been associated with gut dysbiosis and lead to dyslipidemia, hypertension and T2D mellitus [122]. In addition, SCFAs have the ability to modulate CVD risk factors, including blood pressure reduction and regulation of glucose and lipid homeostasis [123].

To this end, the impact of Daily Body Restore (DBR) (a proprietary blend of nine probiotic organisms of the genera Lactobacillus and Bifidobacterium and ten digestive enzymes) on cholesterol metabolism using an in vitro system and a mouse model of hypercholesterolemia induced by a high fat diet. Hypercholesterolemic mice were supplemented with DBR in their drinking water for eight weeks and compared to control mice given low fat diets or unsupplemented high fat diets. As a result, it was found that the probiotic-enzyme supplement used increased the microbiological production of propionic acid in colon reactors and also lowered harmful LDL and increased HDL levels in a mouse model [124].

A different study was designed to determination of the probiotic effect of Lactobacillus fermentum 296 on cardiometabolic disorders induced by high-fat diet in a rat model [122]. The probiotic was administrated by oral gavage to rats for 4 weeks. Results of this research suggest the ability of Lactobacillus fermentum 296 improve cardiovascular and biochemical parameters altered in cardiometabolic disorders. The increased production of short-chain fatty acids which modulate vasodilatation and induce hypotension has been proposed as possible mechanism of action this probiotic strain [122].

\subsection{Autism Spectrum Disorders (ASD)}

ASD is a collection of neurodevelopmental disorders (including impaired social interaction, communication, and repetitive and stereotyped patterns of behaviors) with evidence of genetic predisposition [125]. Intestinal imbalance and compositional changes in gut microbiome in ASD patients are reported. However, the role of intestinal microbiome in brain disorders is poorly documented. Children with ASD have often been reported to have gastrointestinal problems that are more frequent and more severe than in children from the general population. A strong correlation of gastrointestinal symptoms with the severity of ASD was confirmed in studies of the feces 58 children with ASD (of which half received a daily probiotic and half did not receive one) and 39 healthy children (who did not receive a probiotic) [107]. In the feces of children with ASD, significantly lower levels of SCFAs (including acetate, propionate and valerate) compared to healthy children and children with ASD taking probiotics were found. In addition, results of these research indicate an imbalance of gut microbiota in children with ASD (Table 5) [107].

\subsection{Atopic Dermatitis (AD)}

Presumably, intestinal microbiome dysbiosis is also associated with AD. This was confirmed in studies in which 19 children with atopic dermatitis and 18 healthy individuals were given a probiotic (Bifidobacterium breve BR03, Lactobacillus salivarius LS01) for 20 days. It was found that AD is characterized by dysbiosis of the intestinal microbiome with a predominance of some species such as Faecalibacterium, Oscillospira, Bacteroides, Parabacteroides, and Sutterella, that can act as possible biomarkers associated with the disease. In addition, a reduction or absence of some microorganisms, including those producing SCFAs (Bifidobacterium, Blautia, Coprococcus, Eubacterium, and Propionibacterium) with anti-inflammatory effects or involved in immune homeostasis, which might have a protective role against $\mathrm{AD}$, has been identified. However, no significant changes were observed in the composition of intestinal microorganisms and the concentration of SCFAs in children with AD as a result of probiotic supplementation (Table 5) [108]. Therefore, differences in the composition of the intestinal 
microbiome of healthy children and those with AD may suggest that other probiotics be tested to restore intestinal homeostasis.

\subsection{Gastrointestinal Disorders}

SCFAs have a significant impact on preventing colonization of intestinal epithelium by pathogens. Current research shows that the effect of probiotic microorganisms in preventing pathogen infection is maintaining intestinal barrier or immune regulation [126]. Research on probiotics in gastrointestinal disorders has made huge progress in recent years. According to scientists Lactobacillus casei has anti-inflammatory effects on human intestinal epithelial cells infected by Shigella [127]. In addition, probiotic formulas can treat and prevent diarrhea caused by bacterial and viral infections [128]. Probiotics are effective in preventing Clostridium difficile infection [129]. Twenty-two children with shigellosis and 11 children with salmonellosis were examined for ten days, Lactobacillus rhamnosus GG and comparatively antibacterial drug (TMP-SMX or Polymyxin) were administered for five days and then the SCFAs content in the feces was evaluated. Iso-caproic acid was not found in children receiving the probiotic strain, but an increase in fecal propionic acid concentration was observed. Iso-caproic acid is not found in healthy adults and may be indicative of Clostridium difficile (Table 5) [106]. Probiotics prevented C. difficile infection [67] and in randomized clinical studies, prophylactic supplementation of Lactobacillus GG (LGG) to children reduced the incidence of HRV disease [68].

\section{Conclusions}

Maintaining the balance of the intestinal microbiome is crucial for maintaining normal human health and preventing many diseases. Short-chain fatty acids, as metabolites of intestinal bacteria, perform many important functions. The concentration of SCFAs depends on the composition and size of the population of intestinal microorganisms, genetic factors, environmental factors and the diet conditioning access to appropriate substrates. Imbalance of the intestinal microbiome and a decrease in the number of bacteria producing metabolites such as SCFAs (e.g., acetic, propionic and butyric acid) are often diagnosed in patients with inflammatory bowel diseases (IBD), irritable bowel syndrome (IBS), type 2 diabetes (T2D), obesity, infections bacterial, autoimmune disorders, or cancer patients. Numerous scientific reports confirm the effectiveness of probiotics in modulating the intestinal microbiome and their effect on the SCFAs content in the colon. Many studies, in addition to acting in the digestive system, concern the effect of SCFAs produced by intestinal microbiome on functions of distant tissues and organs. Researchers highlight the immunomodulatory effect of SCFAs produced by probiotics, but the mechanisms of their action still need further study. The use of probiotic microorganisms to prevent and treat intestinal dysbiosis, leading to an increase in SCFAs in the colon, seems to be an important direction for further research. Research on SCFAs in relation to diseases covered by the review is much-needed to understand their etiology and pathogenesis, and to propose new therapies. Clinical studies in human populations in this area are highly desirable.

Author Contributions: P.M.-K. initiated the manuscript concept and wrote the manuscript. K.Ś. wrote the manuscript. All authors have read and agreed to the published version of the manuscript.

Funding: This research received no external funding.

Conflicts of Interest: The authors declare no conflict of interest.

\section{References}

1. Baj, J.; Bartosik, D.; Dziewit, Ł.; Jagusztyn-Krynicka, E.K.; Markiewicz, Z.; Piekarowicz, A.; Włodarczyk, M.; Wolska, K.I. Biologia Molekularna Bakterii, 2nd ed.; Wydawnictwo Naukowe PWN SA: Warszawa, Polska, 2015; pp. 133-137, 417.

2. Joseph, N.; Vasodavan, K.; Saipudin, N.A.; Yusof, B.N.M.; Kumar, S.; Nordin, S.A. Gut microbiota and short-chain fatty acids (SCFAs) profiles of normal and overweight school children in Selangor after probiotics administration. J. Funct. Foods 2019, 57, 103-111. [CrossRef] 
3. Martens, J.H.; Barg, H.; Warren, M.J.; Jahn, D. Microbial production of vitamin B12. Appl. Microbiol. Biotechnol. 2002, 58, 275-285. [CrossRef] [PubMed]

4. LeBlanc, J.G.; Milani, C.; de Giori, G.S.; Sesma, F.; van Sinderen, D.; Ventura, M. Bacteria as vitamin suppliers to their host: A gut microbiota perspective. Curr. Opin. Biotechnol. 2013, 24, 160-168. [CrossRef] [PubMed]

5. LeBlanc, J.G.; Chain, F.; Martín, R.; Bermúdez-Humarán, L.G.; Courau, S.; Langella, P. Beneficial effects on host energy metabolism of short-chain fatty acids and vitamins produced by commensal and probiotic bacteria. Microb. Cell Fact. 2017, 16, 1-10. [CrossRef] [PubMed]

6. Czajkowska, A.; Szponar, B. Krótkołańcuchowe kwasy tłuszczowe (SCFA) jako produkty metabolizmu bakterii jelitowych oraz ich znaczenie dla organizmu gospodarza. Postęp. Hig. Med. Doswiadczalnej 2018, 72, 131-142. [CrossRef]

7. Kuczyńska, B.; Wasilewska, A.; Biczysko, M.; Banasiewicz, T.; Drews, M. Krótkołańcuchowe kwasy tłuszczowe - mechanizm działania, potencjalne zastosowanie kliniczne oraz zalecenia dietetyczne. Now. Lek. 2011, 80, 299-304.

8. Havenaar, R. Intestinal health functions of colonic microbial metabolites: A review. Benef. Microbes 2011, 2, 103-114. [CrossRef]

9. Markowiak, P.; Śliżewska, K. Effects of probiotics, prebiotics, and synbiotics on human health. Nutrients 2017, 9, 1021. [CrossRef]

10. Bhutia, Y.D.; Ganapathy, V. Short, but Smart: SCFAs Train T Cells in the Gut to Fight Autoimmunity in the Brain. Immunity 2015, 43, 629-631. [CrossRef]

11. Riviere, A.; Selak, M.; Lantin, D.; Leroy, F.; De Vuyst, L. Bifidobacteria and Butyrate-Producing Colon Bacteria: Importance and Strategies for Their Stimulation in the Human Gut. Front. Microbiol. 2016, 7, 979. [CrossRef]

12. Sun, M.; Wu, W.; Liu, Z.; Cong, Y. Microbiota metabolite short chain fatty acids, GPCR, and inflammatory bowel diseases. J. Gastroenterol. 2017, 52, 1-8. [CrossRef]

13. Hu, J.; Lin, S.; Zheng, B.; Cheung, P.C.K. Short-chain fatty acids in control of energy metabolism. Crit. Rev. Food Sci. Nutr. 2018, 58, 1243-1249. [CrossRef] [PubMed]

14. Nagpal, R.; Wang, S.; Ahmadi, S.; Hayes, J.; Gagliano, J.; Subashchandrabose, S.; Kitzman, D.W.; Becton, T.; Read, R.; Yadav, H. Human-origin probiotic cocktail increases short-chain fatty acid production via modulation of mice and human gut microbiome. Sci. Rep. 2018, 8, 12649. [CrossRef] [PubMed]

15. Cani, P.D. Metabolism in 2013: The gut microbiota manages host metabolism. Nat. Rev. Endocrinol. 2014, 10, 74-76. [CrossRef] [PubMed]

16. Rouxinol-Dias, A.L.; Pinto, A.R.; Janeiro, C.; Rodrigues, D.; Moreira, M.; Dias, J.; Pereira, P. Probiotics for the control of obesity-Its effect on weight change. Porto Biomed. J. 2016, 1, 12-24. [CrossRef]

17. Chakraborti, C.K. New-found link between microbiota and obesity. World J. Gastrointest. Pathophysiol. 2015, 6, 110. [CrossRef]

18. Raoult, D. Probiotics and obesity: A link? Nat. Rev. Microbiol. 2009. [CrossRef]

19. Sanz, Y.; Rastmanesh, R.; Agostonic, C. Understanding the role of gut microbes and probiotics in obesity: How far are we? Pharmacol. Res. 2013, 69, 144-155. [CrossRef]

20. Sokol, H.; Pigneur, B.; Watterlot, L.; Lakhdari, O.; Bermudez-Humaran, L.G.; Gratadoux, J.J.; Blugeon, S.; Bridonneau, C.; Furet, J.P.; Corthier, G.; et al. Faecalibacterium prausnitzii is an anti-inflammatory commensal bacterium identified by gut microbiota analysis of Crohn disease patients. Proc. Natl. Acad. Sci. USA 2008, 105, 16731-16736. [CrossRef]

21. Miquel, S.; Martin, R.; Rossi, O.; Bermudez-Humaran, L.G.; Chatel, J.M.; Sokol, H.; Thomas, M.; Wells, J.M.; Langella, P. Faecalibacterium prausnitzii and human intestinal health. Curr. Opin. Microbiol. 2013, 16, $255-261$. [CrossRef]

22. Payne, A.N.; Chassard, C.; Zimmermann, M.; Müller, P.; Stinca, S.; Lacroix, C. The metabolic activity of gut microbiota in obese children is increased compared with normal-weight children and exhibits more exhaustive substrate utilization. Nutr. Diabetes 2011, 1, e12. [CrossRef] [PubMed]

23. Murugesan, S.; Ulloa-Martínez, M.; Martínez-Rojano, H.; Galván-Rodríguez, F.M.; Miranda-Brito, C.; Romano, M.C.; García-Mena, J. Study of the diversity and short-chain fatty acids production by the bacterial community in overweight and obese Mexican children. Eur. J. Clin. Microbiol. 2015, 34, 1337-1346. [CrossRef] [PubMed]

24. Nagata, S.; Chiba, Y.; Wang, C.; Yamashiro, Y. The effects of the Lactobacillus casei strain on obesity in children: A pilot study. Benef. Microbes 2017, 8, 535-543. [CrossRef] [PubMed] 
25. Food and Agriculture Organization (FAO). Guidelines for the Evaluation of Probiotics in Food. Report of a Joint FAO/WHO Working Group on Drafting Guidelines for the Evaluation of Probiotics in Food; FAO: London, ON, Canada, 2002.

26. Hill, C.; Guarner, F.; Reid, G.; Gibson, G.R.; Merenstein, D.J.; Pot, B.; Morelli, L.; Canani, R.B.; Flint, H.J.; Salminen, S.; et al. Expert consensus document: The International Scientific Association for Probiotics and Prebiotics consensus statement on the scope and appropriate use of the term probiotic. Nat. Rev. Gastroenterol. Hepatol. 2014, 11, 506-514. [CrossRef]

27. Van Zanten, G.C.; Knudsen, A.; Roytio, H.; Forssten, S.; Lawther, M.; Blennow, A.; Lahtinen, S.J.; Jakobsen, M.; Svensson, B.; Jespersen, L. The effect of selected synbiotics on microbial composition and short-chain fatty acid production in a model system of the human colon. PLoS ONE 2012, 7, e47212. [CrossRef] [PubMed]

28. Ríos-Covián, D.; Ruas-Madiedo, P.; Margolles, A.; Gueimonde, M.; de los Reyes-Gavilán, C.G.; Salazar, N. Intestinal Short Chain Fatty Acids and their Link with Diet and Human Health. Front. Microbiol. 2016, 7, 1-9. [CrossRef]

29. PubChem. Explore Chemistry. Available online: https://pubchem.ncbi.nlm.nih.gov/ (accessed on 29 November 2019).

30. Morrison, D.J.; Preston, T. Formation of short chain fatty acids by the gut microbiota and their impact on human metabolism. Gut Microbes 2016, 7, 189-200. [CrossRef]

31. Miller, T.L.; Wolin, M.J. Pathways of acetate, propionate, and butyrate formation by the human fecal microbial flora. Appl. Environ. Microbiol. 1996, 62, 1589-1592. [CrossRef]

32. Flint, H.J.; Duncan, S.H.; Scott, K.P.; Louis, P. Links between diet, gut microbiota composition and gut metabolism. Proc. Nutr. Soc. 2015, 74, 13-22. [CrossRef]

33. Koh, A.; De Vadder, F.; Kovatcheva-Datchary, P.; Bäckhed, F. From dietary fiber to host physiology: Short-chain fatty acids as key bacterial metabolites. Cell 2016, 165, 1332-1345. [CrossRef]

34. Reichardt, N.; Duncan, S.H.; Young, P.; Belenguer, A.; McWilliam Leitch, C.; Scott, K.P.; Louis, P. Phylogenetic distribution of three pathways for propionate production within the human gut microbiota. ISME J. 2014, 8, 1323-1335. [CrossRef] [PubMed]

35. Louis, P.; Hold, G.L.; Flint, H.J. The gut microbiota, bacterial metabolites and colorectal cancer. Nat. Rev. Microbiol. 2014, 12, 661-672. [CrossRef] [PubMed]

36. Vital, M.; Howe, A.C.; Tiedje, J.M. Revealing the bacterial butyrate synthesis pathways by analyzing (meta)genomic data. mBio 2014, 5, e00889. [CrossRef] [PubMed]

37. Serpa, J.; Caiado, F.; Carvalho, T.; Torre, C.; Goncalves, L.G.; Casalou, C.; Lamosa, P.; Rodrigues, M.; Zhu, Z.; Lam, E.W.; et al. Butyrate-rich colonic microenvironment is a relevant selection factor for metabolically adapted tumor cells. J. Biol. Chem. 2010, 285, 39211-39223. [CrossRef] [PubMed]

38. Pessione, E. Lactic acid bacteria contribution to gut microbiota complexity: Lights and shadows. Front. Cell. Infect. Microbiol. 2012, 2, 86. [CrossRef] [PubMed]

39. Meimandipour, A.; Hair-Bejo, M.; Shuhaimi, M.; Azhar, K.; Soleimani, A.F.; Rasti, B.; Yazid, A.M. Gastrointestinal tract morphological alteration by unpleasant physical treatment and modulating role of Lactobacillus in broilers. Br. Poult. Sci. 2010, 51, 52-59. [CrossRef]

40. Salazar, N.; Binetti, A.; Gueimonde, M.; Alonso, A.; Garrido, P.; Gonzalez del Rey, C.; de los Reyes-Gavilan, C.G.; Gonzalez, C.; Ruas-Madiedo, P.; de los Reyes-Gavilan, C.G. Safety and intestinal microbiota modulation by the exopolysaccharide-producing strains Bifidobacterium animalis IPLA R1 and Bifidobacterium longum IPLA E44 orally administered to Wistar rats. Int. J. Food Microbiol. 2011, 144, 342-351. [CrossRef]

41. Sivieri, K.; Morales, M.L.; Adorno, M.A.; Sakamoto, I.K.; Saad, S.M.; Rossi, E.A. Lactobacillus acidophilus CRL 1014 improved "gut health" in the SHIME reactor. BMC Gastroenterol. 2013, 13, 100. [CrossRef]

42. Amaretti, A.; Bernardi, T.; Tamburini, E.; Zanoni, S.; Lomma, M.; Matteuzzi, D.; Rossi, M. Kinetics and metabolism of Bifidobacterium adolescentis MB 239 growing on glucose, galactose, lactose, and galactooligosaccharides. Appl. Environ. Microbiol. 2007, 73, 3637-3644. [CrossRef]

43. Abdin, A.A.; Saeid, E.M. An experimental study on ulcerative colitis as a potential target for probiotic therapy by Lactobacillus acidophilus with or without "olsalazine". J. Crohns Colitis 2008, 2, 296-303. [CrossRef]

44. Englyst, H.N.; Kingman, S.M.; Cummings, J.H. Classification and measurement of nutritionally important starch fractions. Eur. J. Clin. Nutr. 1992, 46, S33-S50. [PubMed] 
45. Flint, H.J.; Scott, K.P.; Duncan, S.H.; Louis, P.; Forano, E. Microbial degradation of complex carbohydrates in the gut. Gut Microbes 2012, 3, 289-306. [CrossRef] [PubMed]

46. Martínez, I.; Kim, J.; Duffy, P.R.; Schlegel, V.L.; Walter, J. Resistant starches types 2 and 4 have differential effects on the composition of the fecal microbiota in human subjects. PLoS ONE 2010, 5, e15046. [CrossRef] [PubMed]

47. Food and Agriculture Organization (FAO). FAO Technical Meeting on Prebiotics: Food Quality and Standards Service (AGNS); FAO: Rome, Italy, 2007.

48. Chaia, A.; Olivier, G. Intestinal Microflora and Metabolic Activity. In Gut Flora, Nutrition, Immunity and Health; Wiley-Blackwell: Hoboken, NJ, USA, 2003; pp. 77-98.

49. Louis, P.; Scott, K.P.; Duncan, S.H.; Flint, H.J. Understanding the effects of diet on bacterial metabolism in the large intestine. J. Appl. Microbiol. 2007, 102, 1197-1208. [CrossRef]

50. Topping, D.L.; Clifton, P.M. Short-chain fatty acids and human colonic function: Roles of resistant starch and nonstarch polysaccharides. Physiol. Rev. 2001, 81, 1031-1064. [CrossRef]

51. Ran-Ressler, R.R.; Glahn, R.P.; Bae, S.; Brenna, J.T. Branched Chain Fatty Acids (BCFA) in the neonatal gut, and estimeated dietary intake in infacy and adulthood. Nestle Nutr. Inst. Work. Ser. 2013, 77, 133-143.

52. Inoue, D.; Tsujimoto, G.; Kimura, I. Regulation of energy homeostasis by GPR41. Front. Endocrinol. (Lausanne) 2014, 5, 81. [CrossRef]

53. Bergman, E.N. Energy contributions of volatile fatty acids from the gastrointestinal tract in various species. Physiol. Rev. 1990, 70, 567-590. [CrossRef]

54. Keshteli, A.H.; Madsen, K.L.; Dieleman, L.A. Diet in the Pathogenesis and Management of Ulcerative Colitis; A Review of Randomized Controlled Dietary Interventions. Nutrients 2019, 11, 1498. [CrossRef]

55. Ratajczak, W.; Rył, A.; Mizerski, A.; Walczakiewicz, K.; Sipak, O.; Laszczyńska, M. Immunomodulatory potential of gut microbiome-derived short-chain fatty acids (SCFAs). Acta Biochim. Pol. 2019, 66, 1-12. [CrossRef]

56. Dalile, B.; Van Oudenhove, L.; Vervliet, B.; Verbeke, K. The role of short-chain fatty acids in microbiotagut-brain communication. Nat. Rev. Gastroenterol. Hepatol. 2019, 16, 461-478. [CrossRef] [PubMed]

57. Le Poul, E.; Loison, C.; Struyf, S.; Springael, J.Y.; Lannoy, V.; Decobecq, M.E.; Brezillon, S.; Dupriez, V.; Vassart, G.; Van Damme, J.; et al. Functional characterization of human receptors for short chain fatty acids and their role in polymorphonuclear cell activation. J. Biol. Chem. 2003, 278, 25481-25489. [CrossRef]

58. Tan, J.; McKenzie, C.; Potamitis, M.; Thorburn, A.N.; Mackay, C.R.; Macia, L. Chapter Three-The Role of Short-Chain Fatty Acids in Health and Disease. Adv. Immunol. 2014, 121, 91-119. [PubMed]

59. Alex, S.; Lange, K.; Amolo, T.; Grinstead, J.S.; Haakonsson, A.K.; Szalowska, E.; Kersten, S. Short-chain fatty acids stimulate angiopoietinlike 4 synthesis in human colon adenocarcinoma cells by activating peroxisome proliferator-activated receptor. Mol. Cell. Biol. 2013, 33, 1303-1316. [CrossRef] [PubMed]

60. Korek, E.; Krauss, H. Novel adipokines: Their potential role in the pathogenesis of obesity and metabolic disorders. Postęp. Hig. Med. Doswiadczalnej 2015, 69, 799-810. [CrossRef] [PubMed]

61. Ohira, H.; Tsutsui, W.; Fujioka, Y. Are Short Chain Fatty Acids in Gut Microbiota Defensive Players for Inflammation and Atherosclerosis? J. Atheroscler. Thromb. 2017, 24, 660-672. [CrossRef] [PubMed]

62. Clausen, M.R.; Mortensen, P.B. Kinetic studies on colonocyte metabolism of short chain fatty acids and glucose in ulcerative colitis. Gut 1995, 37, 684-689. [CrossRef]

63. Van der Beek, C.M.; Bloemen, J.G.; van den Broek, M.A.; Lenaerts, K.; Venema, K.; Buurman, W.A.; Dejong, C.H. Hepatic Uptake of Rectally Administered Butyrate Prevents an Increase in Systemic Butyrate Concentrations in Humans. J. Nutr. 2015, 145, 2019-2024. [CrossRef]

64. Hamer, H.M.; Jonkers, D.M.; Renes, I.B.; Vanhoutvin, S.A.; Kodde, A.; Troost, F.J.; Venema, K.; Brummer, R.J. Butyrate enemas do not affect human colonic MUC2 and TFF3 expression. Eur. J. Gastroen. Hepat. 2010, 22, 1134-1140. [CrossRef]

65. Hague, A.; Elder, D.J.E.; Hicks, D.J.; Paraskeva, C. Apoptosis in colorectal tumor cells: Induction by the short chain fatty acids butyrate, propionate and acetate and by the bile salt deoxycholate. Int. J. Cancer 1995, 60, 400-406. [CrossRef]

66. Hijowa, E.; Chmelarova, A. Short chain fatty acids and colonic health. Bratisl. Lek. Listy 2007, 108, 354-358.

67. Donohoe, D.R.; Collins, L.B.; Wali, A.; Bigler, R.; Sun, W.; Bultman, S.J. The Warburg effect dictates the mechanism of butyrate-mediated histone acetylation and cell proliferation. Mol. Cell 2012, 48, 612-626. [CrossRef] [PubMed] 
68. Kotunia, A.; Pietrzak, P.; Guilloteau, P.; Zabielski, R. Kwas masłowy w przewodzie pokarmowym. Prz. Gastroenterol. 2010, 5, 117-122.

69. Sobotka, L. Podstawy żywienia Klinicznego; Wydawnictwo Lekarskie PZWL: Warszawa, Polska, 2008.

70. Chambers, E.S.; Preston, T.; Frost, G.; Morrison, D.J. Role of Gut Microbiota-Generated Short-Chain Fatty Acids in Metabolic and Cardiovascular Health. Curr. Nutr. Rep. 2018, 7, 198-206. [CrossRef]

71. Bereswill, S.; Fischer, A.; Plickert, R.; Haag, L.M.; Otto, B.; Kuhl, A.A.; Dasti, J.I.; Zautner, A.E.; Munoz, M.; Loddenkemper, C.; et al. Novel murine infection models provide deep insights into the "menage a trois" of Campylobacter jejuni, microbiota and host innate immunity. PLoS ONE 2011, 6, e20953. [CrossRef]

72. Vanderhaeghen, S.; Lacroix, C.; Schwab, C. Methanogen communities in stools of humans of different age and health status and co-occurrence with bacteria. FEMS Microbiol. Lett. 2015, 362, fnv092. [CrossRef]

73. Layden, B.T.; Angueira, A.R.; Brodsky, B.; Durai, V.; Lowe, W.L. Short chain fatty acids and their receptors: New metabolic targets. Transl. Res. 2013, 161, 131-140. [CrossRef]

74. Arora, T.; Sharma, R. Fermentation potential of the gut microbiome: Implications for energy homeostasis and weight management. Nutr. Rev. 2011, 69, 99-106. [CrossRef]

75. Russell, W.R.; Hoyles, L.; Flint, H.J.; Dumas, M.E. Colonic bacterial metabolites and human health. Curr. Opin. Microbiol. 2013, 16, 246-254. [CrossRef] [PubMed]

76. Henningsson, A.M.; Nyman, E.M.; Björck, I.M. Content of short-chain fatty acids in the hindgut of rats fed processed bean (Phaseolus vulgaris) flours varying in distribution and content of indigestible carbohydrates. Br. J. Nutr. 2001, 86, 379-389. [CrossRef]

77. Al-Lahham, S.H.; Peppelenbosch, M.P.; Roelofsen, H.; Vonk, R.J.; Venema, K. Biological effects of propionic acid in humans; metabolism, potential applications and underlying mechanisms. Biochim. Biophys. Acta 2010, 1801, 1175-1183. [CrossRef] [PubMed]

78. Böcker, U.; Nebe, T.; Herweck, F.; Holt, L.; Panja, A.; Jobin, C.; Rossol, S.; Sartor, R.B.; Singer, M.V. Butyrate modulates intestinal epithelial cell-mediated neutrophil migration. Clin. Exp. Immunol. 2003, 131, 53-60. [CrossRef] [PubMed]

79. Liang, Y.; Liang, S.; Zhang, Y.; Deng, Y.; He, Y.; Chen, Y.; Liu, C.; Lin, C.; Yang, Q. Oral administration of compound probiotics ameliorates hfd-induced gut microbe dysbiosis and chronic metabolic inflammation via the g protein-coupled receptor 43 in non-alcoholic fatty liver disease rats. Probiotics Antimicrob. Proteins 2018, 11, 175-185. [CrossRef] [PubMed]

80. Onrust, L.; Van Driessche, K.; Ducatelle, R.; Schwarzer, K.; Haesebrouck, F.; Van Immerseel, F. Valeric acid glyceride esters in feed promote broiler performance and reduce the incidence of necrotic enteritis. Poult. Sci. 2018, 97, 2303-2311. [CrossRef] [PubMed]

81. Yuille, S.; Reichardt, N.; Panda, S.; Dunbar, H.; Mulder, I.E. Human gut bacteria as potent class I histone deacetylase inhibitors in vitro through production of butyric acid and valeric acid. PLOS ONE 2018, 13, e0201073. [CrossRef] [PubMed]

82. Fukuda, S.; Toh, H.; Hase, K.; Oshima, K.; Nakanishi, Y.; Yoshimura, K.; Tobe, T.; Clarke, J.M.; Topping, D.L.; Suzuki, T.; et al. Bifidobacteria can protect from enteropathogenic infection through production of acetate. Nature 2011, 469, 543-547. [CrossRef]

83. Wollowski, I.; Rechkemmer, G.; Pool-Zobel, B.L. Protective role of probiotics and prebiotics in colon cancer. Am. J. Clin. Nutr. 2001, 73, 451s-455s. [CrossRef]

84. Wang, Y.; Guo, Y.; Chen, H.; Wei, H.; Wan, C. Potential of lactobacillus plantarum zdy2013 and bifidobacterium bifidum wbin03 in relieving colitis by gut microbiota, immune, and anti-oxidative stress. Can. J. Microbiol. 2018, 64, 327-337. [CrossRef]

85. Luhrs, H.; Gerke, T.; Muller, J.G.; Melcher, R.; Schauber, J.; Boxberger, F.; Scheppach, W.; Menzel, T. Butyrate inhibits NF-kappa B activation in lamina propria macrophages of patients with ulcerative colitis. Scand. J. Gastroenterol. 2002, 37, 458-466. [CrossRef]

86. Harig, J.M.; Soergel, K.H.; Komorowski, R.A.; Wood, C.M. Treatment of diversion colitis with short-chain-fatty acid irrigation. N. Engl. J. Med. 1989, 320, 23-28. [CrossRef]

87. Berggren, A.M.; Nyman, E.M.G.L.; Lundquist, I.; Björck, I.M.E. Influence of orally and rectally administered propionate on cholesterol and glucose metabolism in obese rats. Br. J. Nutr. 1996, 76, 287-294. [CrossRef] [PubMed] 
88. Jan, G.; Belzacq, A.S.; Haouzi, D.; Rouault, A.; Metivier, D.; Kroemer, G.; Brenner, C. Propionibacteria induce apoptosis of colorectal carcinoma cells via short-chain fatty acids acting on mitochondria. Cell Death Differ. 2002, 9, 179-188. [CrossRef] [PubMed]

89. Li, C.J.; Elsasser, T.H. Butyrate-induced apoptosis and cell cycle arrest in bovine kidney epithelial cells: Involvement of caspase and proteasome pathways. J. Anim. Sci. 2005, 83, 89-97. [CrossRef] [PubMed]

90. Yoo, J.Y.; Kim, S.S. Probiotics and prebiotics: Present status and future perspectives on metabolic disorders. Nutrients 2016, 8, 173. [CrossRef] [PubMed]

91. Moens, F.; Van den Abbeele, P.; Basit, A.W.; Dodoo, D.; Chatterjee, R.; Smith, B.; Gaisford, S. A four-strain probiotic exerts positive immunomodulatory effects by enhancing colonic butyrate production in vitro. Int. J. Pharm. 2019, 555, 1-10. [CrossRef] [PubMed]

92. Wang, L.; Zhang, J.; Guo, Z.; Kwok, L.; Ma, C.; Zhang, W.; Lv, Q.; Huang, W.; Zhang, H. Effect of oral consumption of probiotic Lactobacillus planatarum P-8 on fecal microbiota, SIgA, SCFAs, and TBAs of adults of different ages. Nutrition 2014, 30, 776-783. [CrossRef] [PubMed]

93. Ho, S.-T.; Hsieh, Y.-T.; Wang, S.-Y.; Chen, M.-J. Improving effect of a probiotic mixture on memory and learning abilities in d-galactose-treated aging mice. J. Dairy Sci. 2019, 102, 1901-1909. [CrossRef]

94. Pérez-Burillo, S.; Pastoriza, S.; Gironés, A.; Avellaneda, A.; Pilar Francino, M.; Rufián-Henares, J.A. Potential probiotic salami with dietary fiber modulates metabolism and gut microbiota in a human intervention study. J. Funct. Foods 2020, 66, 103790. [CrossRef]

95. Dos Reis, S.A.; Da Conceição, L.L.; Siqueira, N.P.; Rosa, D.D.; Da Silva, L.L.; Peluzio, M.D.C.G. Review of the mechanisms of probiotic actions in the prevention of colorectal cancer. Nutr. Res. 2017, 37, 1-19. [CrossRef]

96. World Health Organization WHO. Global Health Observatory: Cancer Mortality and Morbidity. Available online: http://www.who.int/gho/ncd/mortality_morbidity/cancer_text/en/ (accessed on 14 March 2020).

97. Ohkawara, S.; Furuya, H.; Nagashima, K.; Asanuma, N.; Hino, T. Oral administration of Butyrivibrio fbrisolvens, a butyrate-producing bacterium, decreases the formation of aberrant crypt foci in the colon and rectum of mice. J. Nutr. 2005, 135, 2878-2883. [CrossRef]

98. Górska, A.; Przystupski, D.; Niemczura, M.J.; Kulbacka, J. Probiotic Bacteria: A Promising Tool in Cancer Prevention and Therapy. Curr. Microbiol. 2019, 76, 939-949. [CrossRef] [PubMed]

99. Thirabunyanon, M.; Hongwittayakorn, P. Potential probiotic lactic acid bacteria of human origin induce antiproliferation of colon cancer cells via synergic actions in adhesion to cancer cells and short-chain fatty acid bioproduction. Appl. Biochem. Biotechnol. 2013, 169, 511-525. [CrossRef] [PubMed]

100. Grishina, A.; Kulikova, I.; Alieva, L.; Dodson, A.; Rowland, I.; Jin, J. Antigenotoxic effect of kefir and ayran supernatants on fecal water-induced DNA damage in human colon cells. Nutr. Cancer 2011, 63, 73-79. [CrossRef] [PubMed]

101. Chen, Z.F.; Ai, L.-Y.; Wang, J.L.; Ren, L.L.; Yu, Y.N.; Xu, J.; Chen, H.Y.; Yu, J.; Li, M.; Qin, W.X.; et al. Probiotics Clostridium butyricum and Bacillus subtilis ameliorate intestinal tumorigenesis. Futur. Microbiol. 2015, 10, 1433-1445. [CrossRef]

102. Zhu, J.; Zhu, C.; Ge, S.; Zhang, M.; Jiang, L.; Cui, J.; Ren, F. Lactobacillus salivarius Ren prevent the early colorectal carcinogenesis in 1, 2-dimethylhydrazine-induced rat model. J. Appl. Microbiol. 2014, 117, 208-216. [CrossRef]

103. Ohara, T.; Yoshino, K.; Kitajima, M. Possibility of preventing colorectal carcinogenesis with probiotics. Hepatogastroenterology 2010, 57, 1411-1415.

104. Worthley, D.L.; Le Leu, R.; Whitehall, V.L.; Conlon, M.; Christophersen, C.T.; Belobrajdic, D.P.; Mallitt, K.-A.; Hu, Y.; Irahara, N.; Ogino, S.; et al. A human, double-blind, placebo-controlled, crossover trial of prebiotic, probiotic, and synbiotic supplementation: Effects on luminal, inflammatory, epigenetic, and epithelial biomarkers of colorectal cancer. Am. J. Clin. Nutr. 2009, 90, 578-586. [CrossRef]

105. Tonucci, L.B.; Olbrich dos Santos, K.M.; de Oliveira, L.L.; Rocha Ribeiro, S.M.; Stampini, H.; Martino, D. Clinical application of probiotics in type 2 diabetes mellitus: A randomized, double-blind, placebo-controlled study. Clin. Nutr. 2017, 36, 85-92. [CrossRef]

106. Siigur, U.; Tamm, E.; Torm, S.; Lutsar, I.; Salminen, S.; Midtvedt, T. Effect of Bacterial Infection and Administration of a Probiotic on Faecal Short-Chain Fatty Acids. Microb. Ecol. Health Dis. 1996, 9, 271-277. [CrossRef] 
107. Adams, B.J.; Johansen, L.J.; Powell, L.D.; Quig, D.; Rubin, R.A. Gastrointestinal flora and gastrointestinal status in children with autism-comparisons to typical children and correlation with autism severity. BMC Gastroenterol. 2011, 11,1-13. [CrossRef]

108. Reddel, S.; Chierico, F.D.; Quagliariello, A.; Giancristoforo, S.; Vernocchi, P.; Russo, A.; Fiocchi, A.; Rossi, P.; Putignani, L.; Hachem, M.E. Gut microbiota profile in children affected by atopic dermatitis and evaluation of intestinal persistence of a probiotic mixture. Sci. Rep. 2018, 9, 1-10. [CrossRef] [PubMed]

109. Antony, S.; de Leon, M.P. Probiotics and Its Relationship with the Cardiovascular System. In ProbioticsCurrent Knowledge and Future Prospects; Intechopen: London, UK, Chapter 3. Available online: http: //dx.doi.org/10.5772/intechopen.75077 (accessed on 14 March 2020).

110. Tamang, J.; Shin, D.; Jung, S.; Chae, S. Functional Properties of Microorganisms in Fermented Foods. Front. Microbiol. 2016, 7, 578. [CrossRef] [PubMed]

111. Delzenne, N.M.; Neyrinck, A.M.; Backhed, F.; Cani, P.D. Targeting gut microbiota in obesity: Effects of prebiotics and probiotics. Nat. Rev. Endocrinol. 2011, 7, 639-646. [CrossRef] [PubMed]

112. Sanchez, M.; Darimont, C.; Drapeau, V.; Emady-Azar, S.; Lepage, M.; Rezzonico, E.; Ngom-Bru, C.; Berger, B.; Philippe, L.; Ammon-Zuffrey, C.; et al. Effect of Lactobacillus rhamnosus CGMCC1.3724 supplementation on weight loss and maintenance in obese men and women. Br. J. Nutr. 2013, 111, 1507-1519. [CrossRef]

113. Ettinger, G.; MacDonald, K.; Reid, G.; Burton, J.P. The influence of the human microbiome and probiotics on cardiovascular health. Gut Microbes 2014, 5, 719-728. [CrossRef]

114. Vemuri, R.; Gundamaraju, R.; Shinde, T.; Perera, A.P.; Basheer, W.; Southam, B.; Gondalia, S.V.; Karpe, A.V.; Beale, D.J.; Tristram, S.; et al. Lactobacillus acidophilus DDS-1 Modulates Intestinal-Specific Microbiota, Short-Chain Fatty Acid and Immunological Profiles in Aging Mice. Nutrients 2019, 11, 1297. [CrossRef]

115. Huang, Y.C.; Wu, B.H.; Chu, Y.L.; Chang, W.C.; Wu, M.C. Efects of tempeh fermentation with lactobacillus plantarum and rhizopus oligosporus on streptozotocin-induced type II diabetes mellitus in rats. Nutrients 2018, 10, 1143. [CrossRef]

116. Mu, W.C.; Van Hoosier, E.; Elks, C.; Grant, R. Long-term efects of dietary protein and branched-chain aminoacids on metabolism and inflammation in mice. Nutrients 2018, 10, 918. [CrossRef]

117. Moya-Perez, A.; Neef, A.; Sanz, Y. Bifidobacterium pseudocatenulatum CECT 7765 reduces obesity-associated inflammation by restoring the lymphocyte-macrophage balance and gut microbiota structure in high-fat diet-fed mice. PLoS ONE 2015, 10, e0126976. [CrossRef]

118. Fontane, L.; Benaiges, D.; Goday, A.; Llaurado, G.; Pedro-Botet, J. Influence of the microbiota and probiotics in obesity. In Clinica e Investigacion Envestigacion en Arteriosclerosis; Elsevier España: Publicacion oficial de la Sociedad Espanola de Arteriosclerosis, 2018; Available online: https://doi.org/10.1016/j.arteri.2018.03.004 (accessed on 14 March 2020).

119. Okubo, T.; Takemura, N.; Yoshida, A.; Sonoyama, K. KK/Ta mice administered Lactobacillus plantarum strain no. 14 have lower adiposity and higher insulin sensitivity. Biosci. Microbiota Food Health 2013, 32, 93-100. [CrossRef]

120. Yadav, H.; Lee, J.H.; Lloyd, J.; Walter, P.; Rane, S.G. Beneficial metabolic effects of a probiotic via butyrate-induced GLP-1 secretion. J. Biol. Chem. 2013, 288, 25088-25097. [CrossRef] [PubMed]

121. Wang, Y.; Dilidaxi, D.; Wu, Y.; Sailike, J.; Sun, X.; Nabi, X. Composite probiotics alleviate type 2 diabetes by regulating intestinal microbiota and inducing GLP-1 secretion in $\mathrm{db} / \mathrm{db}$ mice. Biomed. Pharmacother. 2020, 125, 109914. [CrossRef] [PubMed]

122. Cavalcante, R.G.S.; de Albuquerque, T.M.R.; de Luna Freire, M.O.; Ferreira, G.A.H.; Carneiro dos Santos, L.A.; Magnani, M.; Cruz, J.C.; Braga, V.A.; de Souza, E.L.; de Brito Alves, J.L. The probiotic Lactobacillus fermentum 296 attenuates cardiometabolic disorders in high fat diet-treated rats. Nutr. Metab. Cardiovasc. Dis. 2019, 29, 1408-1417. [CrossRef] [PubMed]

123. Edwards, C.A.; Havlik, J.; Cong, W.; Mullen, W.; Preston, T.; Morrison, D.J.; Combet, E. Polyphenols and health: Interactions between fibre, plant polyphenols and the gut microbiota. Nutr. Bull. 2017, 42, 356-360. [CrossRef] [PubMed]

124. Ichim, T.E.; Patel, A.N.; Shafer, K.A. Experimental support for the effects of a probiotic/digestive enzyme suplement on serum cholesterol concentrations and the intestinal microbiome. J. Transl. Med. 2016, 14, 1-9. [CrossRef] 
125. Forsyth, A.; Raslan, K.; Lyashenko, C.; Bona, S.; Snow, M.; Khor, B.; Herrman, E.; Ortiz, S.; Choi, D.; Maier, T.; et al. Children with autism spectrum disorder: Pilot studies examining the salivary microbiome and implications for gut metabolism and social behawior. Hum. Microbiome J. 2020, 15, 100066. [CrossRef]

126. Yang, H.; Sun, Y.; Cai, R.; Chen, Y.; Gu, B. The impact of dietary fiber and probiotics in infectious diseases. Microb. Pathog. 2020, 140, 103931. [CrossRef]

127. Marlett, J.A.; Fischer, M.H. The active fraction of psyllium seed husk. Proc. Nutr. Soc. 2013, 62, $207-209$. [CrossRef]

128. Tien, M.T.; Girardin, S.E.; Regnault, B.; Bourhis, L.L.; Dillies, M.A.; Coppe'e, J.Y.; Bourdet-Sicard, R.; Sansonetti, P.J.; Pe'dron, T. Anti-Inflammatory Effect of Lactobacillus casei on Shigella-Infected Human Intestinal Epithelial Cells. J. Immunol. 2006, 176, 1228-1237. [CrossRef]

129. de Vrese, M.; Marteau, P.R. Probiotics and prebiotics: Effects on diarrhea. J. Nutr. 2007, 137, 803S-811S. [CrossRef]

(C) 2020 by the authors. Licensee MDPI, Basel, Switzerland. This article is an open access article distributed under the terms and conditions of the Creative Commons Attribution (CC BY) license (http://creativecommons.org/licenses/by/4.0/). 